\title{
PENGOLAHAN NANOSILIKA DAUN BAMBU ANTI ORGANISME PENGGANGGU TANAMAN SEBAGAI UPAYA PENINGKATAN PEREKONOMIAN MASYARAKAT DI GAMPONG MEURANDEH KOTA LANGSA, ACEH
}

\author{
Zulfan Arico'), Sri Jayanthi' $^{2)}$, Yulina Ismida ${ }^{1)}$, Nuraini' ${ }^{2)}$ \\ ${ }^{1)}$ Fakultas Teknik, Universitas Samudra \\ ${ }^{2)}$ Fakultas Keguruan dan Ilmu Pendidikan, Universitas Samudra \\ aricozulfan@unsam.ac.id
}

DOI : 10.31604/jpm.v2i1.1-7

\begin{abstract}
The level of income in the City of Aceh Province, especially in Gampong Meurandeh is still relatively low. One reason is the use of free time for non-productive homemakers. The purpose of this activity is to improve the ability of homemakers to produce high economic value products by utilizing their free time by utilizing available natural resources, one of which is bamboo plants to be able to increase the family's economic income. The method used in the implementation of the activities carried out jointly with the mothers in Gampong Meurandeh Langsa Lama Subdistrict, Langsa City is by (1) Socialization, implementation, survey, and assistance programme. The current activity has been completed and has produced the superior biopesticide product of the community of Meurandeh Village. The conclusions that can be obtained from the implementation of the program are (a) The high level of participation from the community service program partners has a positive impact on the implementation of the program, seen from training and assistance in making products, (b) The program can produce alamai biopesticides made from bamboo leaf nano silica so that it can improve the economy of the community and the product is environmentally friendly so that it can maintain environmental sustainability. Suggestion, (c) The high interest and enthusiasm of the community in participating in the Community Service program is expected to get special attention so that the program will continue.
\end{abstract}

Keywords: Nanosilica, Bamboo Leaves, Meurandeh Village.

\begin{abstract}
Abstrak
Tingkat pendapatan di Kota Provinsi Aceh Khusunya di Gampong Meurandeh masih tergolong rendah. Salah satu penyebabnya adalah pemanfaatan waktu luang ibu rumah tangga yang belum produktif. Tujuan keiatan ini adalah meningkatkan kemampuan ibu rumah tangga dalam menghasilkan produk bernilai ekonomi tinggi dengan memanfaatkan waktu luangnya dengan cara memanfaatkan sumber daya alam yang tersedia salah satunya adalah tanaman bambu untuk dapat menambah penghasilan perekonomian keluarga. Metode yang digunakan dalam pelaksanaan kegiatan yang dilaksanakan bersama dengan ibu-ibu di Gampong meurandeh Kecamatan Langsa Lama Kota Langsa adalah dengan sosialisasi, pelaksanaan, survey dan pendampingan. Kegiatan saat ini telah selesai dan telah menghasilkan produk biopestisida unggulan masyarakat Gampong Meurandeh. Kesimpulan yang dapat diperoleh dari pelaksanaan
\end{abstract}


program adalah (a) Tingkat partisipasi yang tinggi dari mitra program pengabdian kepada masyarakat memberikan dampak positif bagi pelaksanaan program, terlihat dari pelatihan dan pendampingan dalam pembuatan produk, (b) Pelaksanaan program mampu menghasilakan produk berupa biopestisida alamai yang terbuat dari nanosilika daun bambu sehingga mampu meningkatkan perekonomian masyarakat serta produk tersebut bersifat ramah lingkungan sehingga dapat menjaga kelestraian lingkungan sekitar Saran, (c) Tingginya minat dan antusias masyarakat dalam mengikuti program Pengabdian kepada masyarakat ini diharapkan mendapatkan perhatian khusus, sehingga program ini akan terus berjalan.

Kata kunci: Nanosilika, Daun bambu, Gampong Meurandeh.

\section{PENDAHULUAN}

Gampong Meurandeh

merupakan salah satu Gampong/Desa yang berada Kecamatan Langsa Lama Kota Langsa Provinsi Aceh. Luas wilayah Gampong/Desa Meurandeh sebagian besar digunakan oleh masyarakat sebagai daerah pertanian dan perkebunan, sehingga dapat dikatakan mayoritas pekerjaan masyarakat di Gampong Meurandeh adalah sebagai petani. Tingkat pendapatan di Kota Provinsi Aceh Khusunya di Gampong/Desa Meurandeh masih tergolong rendah. Salah satu penyebabnya adalah pemanfaatan waktu luang ibu rumah tangga yang belum produktif. Padahal ibu rumah tangga merupakan salah satu komponen yang menjadi pilar terciptanya kesejahteraan masyarakat perdesaan. Gampong Meurandeh Kecamatan Langsa Lama Kota Langsa terdapat merupakan desa dengan jumlah penduduk yang padat, tetapi dengan pendapatan dan kesejahteraan masyarakat yang masih tergolong rendah. Padahal terdapat sejumlah potensi pengembangan ekonomi masyarakat desa, khususnya yang dapat dilakukan ibu rumah tangga namun belum dapat tergarap dan dikelola secara optimal. Salah satunya adalah meningkatkan kemampuan ibu rumah tangga dalam menghasilkan produk bernilai ekonomi tinggi dengan memanfaatkan waktu luangnya dengan cara memanfaatkan sumber daya alam yang tersedia salah satunya adalah tanaman bambu untuk dapat menambah penghasilan perekonomian keluarga.

Bambu, termasuk daun bambu memiliki kandungan silika yang tinggi (Suhardiman, 2011). Amu dan Adetuberu (2010) melaporkan bahwa daun bambu dalam bentuk abu mengandung Si02 $75.90 \%$, Al203 4.13 $\%, \mathrm{Fe} 2031.22 \%, \mathrm{Ca} 07.47 \%, \mathrm{Mg} 0$ $1.85 \%$, dan K20 $5.62 \%$. Silika (Si) merupakan salah satu unsur hara yang diperlukan oleh pertumbuhan tanaman dalam jumlah besar. Silika (Si) dikenal seebagai beneficial element, salah satunya yaitu dapat meningkatkan ketersediaan fosfat (P) dalam tanah. Ketersediaan fosfat $(\mathrm{P})$ dipengaruhi oleh konsentrasi logam beracun Fe dan Mn. Fosfat (P) akan berkurang bila konsentrasi $\mathrm{Fe}$ dan $\mathrm{Mn}$ tinggi (Badan Litbangtan, 2010). Fosfat (P) biasa diberikan dalam bentuk pupuk, sedangkan pemberian pupuk di daerah tropik tidak dapat bertahan lama karena cepat terlapukkan sehingga tidak sampai pada tanaman. Oleh karena itu, adanya pemberian silika merupakan alternatif yang dapat dilakukan untuk mengurangi 
serapan fosfat $(\mathrm{P})$ dalam tanah serta menekan logam beracun $\mathrm{Fe}$ dan $\mathrm{Mn}$ dalam tanah sehingga fosfat (P) lebih tersedia. Selain itu, unsur hara silika tidak meninggalkan residu bahan beracun dan berbahaya pada tanaman dan lingkungan. Hal ini dikarenakan kerja dari silika tidak dengan meracuni Organisme Pengganggu Tanaman (OPT) yang dapat menyebabkan kekebalan pada OPT, tetapi sifatnya yang keras seperti batu mampu membentuk lapisan keras (cuticle) sebagai benteng perlindungan dari serangan OPT.

Masyarakat biasa menggunakan pestisida tanaman berasal dari bahanbahan kimia yang membahayakan tanaman dan lingkungan. Selain itu, pestisida untuk pencegahan Organisme Pengganggu Tanaman (OPT) tidak banyak memberikan perubahan dan masih belum efektif untuk menghentikan serangan organisme tersebut, sehingga tanaman terserang penyakit yang tentu akan merugikan masyarakat. Maka dari itu, pemanfaatan silika daun bambu merupakan salah satu solusi pembuatan biopestisida yang dapat dilakukan melalui teknologi pengolahan yang ramah lingkungan. Teknologi pengolahan untuk mendapatkan kualitas biopestisida yang unggul sangat penting. Teknologi pengolahan sangat penting karena pengolahan yang baik akan menghasilkan produk yang baik. Aplikasi teknologi pengolahan dapat memberikan keuntungan baik pada produsen maupun konsumen. Keuntungan bagi produsen yang dalam hal ini adalah dapat meningkatkan hasil panen dengan kualitas yang unggul, sehingga meningkatkan nilai jual ekonomi dan meningkatkan pendapatan. Keuntungan bagi konsumen adalah jaminan mutu terhadap produk yang dibeli serta keamanan produk yang dikonsumsi.

Berdasarkan uraian diatas, kami Tim Pengabdian Kepada Masyarakat Universitas Samudra ingin mengajak masyarakat di Gampong Meurandeh khusunya para ibu rumah tangga untuk memanfaatkan waktu luangnya untuk menghasilkan sebuah produk Biopestisida yang terbuat dari daun bambu sebagai anti Organisme Pengganggu Tanaman (OPT) sebagai upaya meningkatkan perekonomian keluarga.

\section{METODE PELAKSANAAN}

\section{Kerangka Konsep Penyelesaian Masalah}

Berdasarkan analisa situasi dan permasalahan yang dihadapi oleh mitra yaitu masyarakat Gampong Meurandeh Kecamatan Langsa Lama Kota Langsa, maka kerangka konsep penyelesaian masalahnya adalah sebagai berikut: 


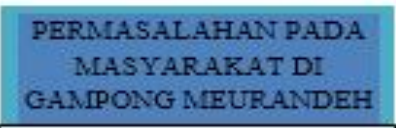

1. Pencemaran air akibat peatisida

2. Hasil panen yang tidak seguai dengan target

3. Rendahnya pendapatan warga Gampong Meurandeh Kota Langas

4. Minimnya pengetahuan warga tentang penggunaan peatisida alami

5. Minimnya perekonomian masyarakat Gampong Meurandeh

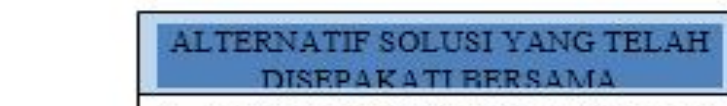

1. Membuat Biopeatisida yang terbuat dari daun bambu sebagai anti Organisme Pengganggu Tanaman

2. Manfaat penggunaan Biopeatisida yang terbuat dari daun bambu sebagai anti Organisme Pengganggu tanaman

3. Mempromosikan produk yang telah dibuat

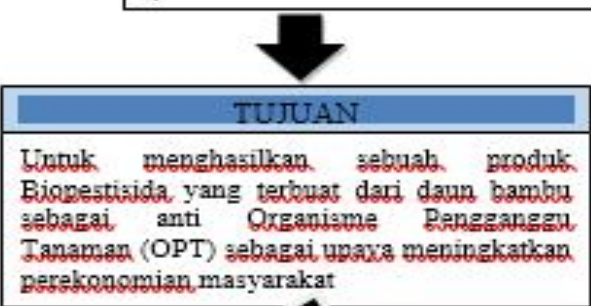
perekcyomian masyarakat

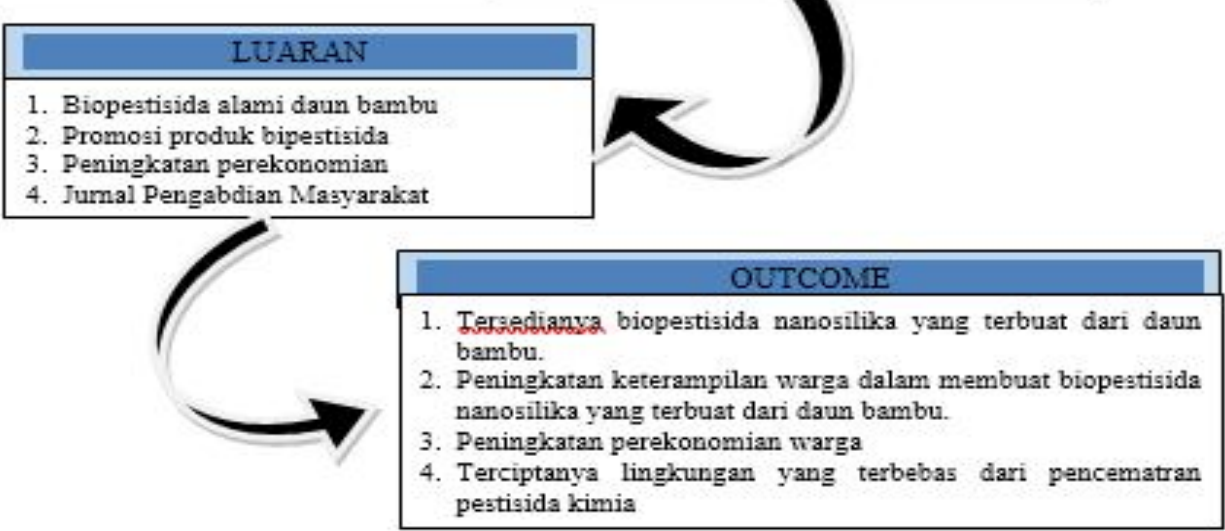

Gambar 1: Kerangka Konsep Penyelesaian Masalah

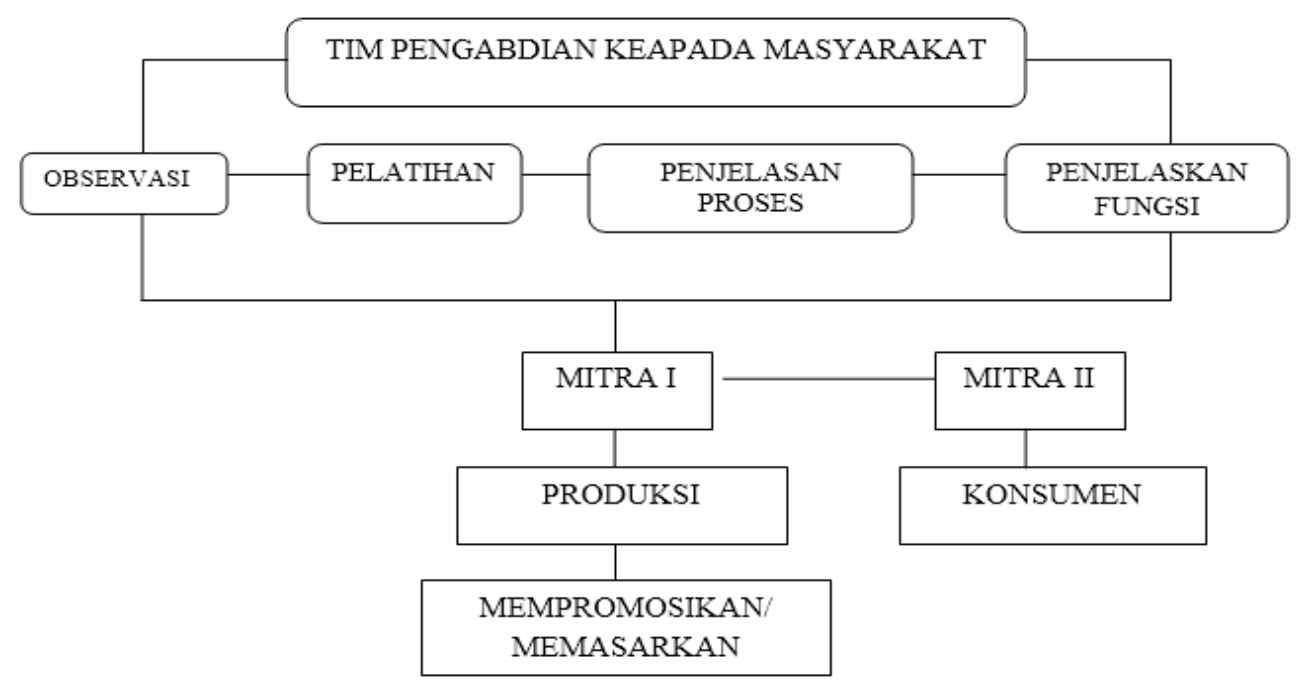

Gambar 2: Prosedur Kerja Untuk Mendukung Realisasi Metode Yang Ditawarkan 
Zulfan Arico, dkk. Pengolahan Nanosilika Daun Bambu Anti Organisme ...

HASIL DAN PEMBAHASAN

Tahapan Hasil Kegiatan

Pelaksanaan

Pengabdian kepada Masyarakat

"Pengolahan Nanosilika Daun Bambu Anti Pengganggu Tanaman Sebagai Upaya Peningkatan Perekonomian Masyarakat di Gampong Meurandeh Kota Langsa, Aceh" yang dilaksanakan bersama dengan ibu-ibu di Gampong meurandeh Kecamatan Langsa Lama
Kota Langsa yang telah berjalan sebesar $100 \%$ (Gambar 3). Adapun program yang sudah berjalan antara lain: sosialisasi tentang pembuatan biopestisida alami dari bambu sebagai anti hama. Kegiatan tersebut masih berlangsung sampai saat ini berupa pendampingan kelompok dalam pembuatan nanosilika dari daun bambu yang nantinya akan dijadikan produk bipestisida unggulan masyarakat Gampong Meurandeh.

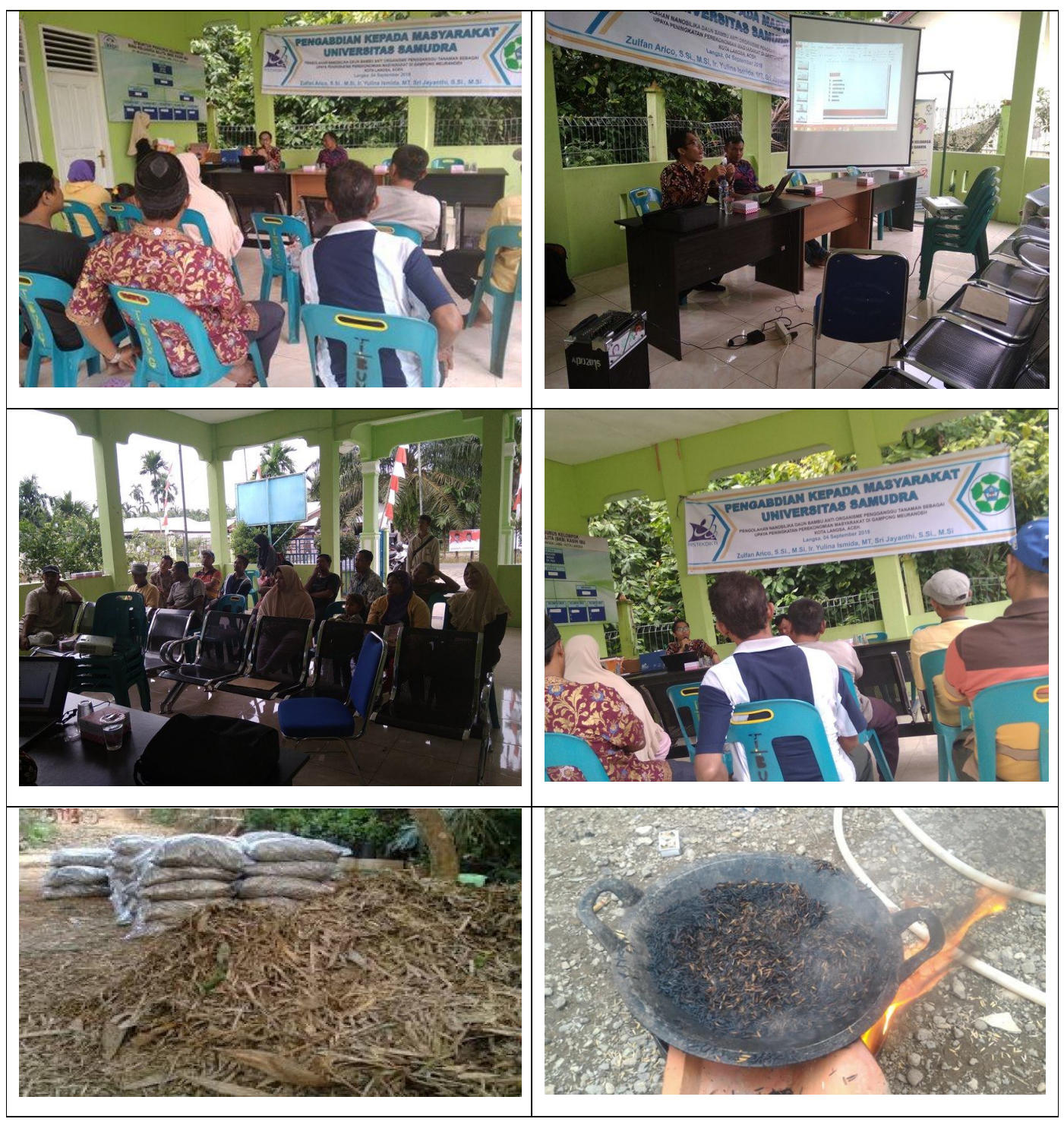

Gambar 3: Dokumentasi Kegiatan Pengolahan Nanosilika Daun Bambu 


\section{Tahapan Evaluasi Kegiatan}

Adapun alur pelaksanaan program pengabdian ini dimulai dari, 1) Tahap persiapan, yang terdiri dari tahap : (a) penyiapan bahan administrasi sesuai dengan kebutuhan pelaksanaan sosialisasi, (b) melakukan koordinasi dengan Geuchik Meurandeh (c) menyiapkan materi pelatihan, (d) menyiapkan jadwal sosialisasi menyesuaikan dengan perencanaan kegiatan yang telah terprogram, 2) tahap pelaksanaan, yang terdiri dari: (a) melakukan sosialisasi pelatihan pengolahan bahan baku (b) diskusi terbatas mengenai pemahaman wawasan mengenai biopestisida alami, dan 3) tahap evaluasi, yang terdiri dari (a) persentasi kesimpulan sosialiasi oleh tim pelaksana dan praktek pelatihan langsung bagi peserta, (b) refleksi berupa praktek dari tim Pengabdian kepada Masyarakat dengan uji coba program yang sudah dilatihkan (Dokumentasi kegiatan pada Lampiran 3). Untuk mengukur tingkat keberhasilan kegiatan yang telah dilakukan, maka akan dilakukan evaluasi minimal 3 (tiga) kali, yaitu evaluasi proses, evaluasi akhir, dan evaluasi tindak lanjut. Kriteria dan indikator pencapaian tujuan dan tolak ukur yang digunakan untuk menjastifikasi tingkat keberhasilan kegiatan.

Berdasarkan hasil evaluasi lebih lanjut juga terekam, beberapa manfaat praktis yang diperoleh oleh ibu-ibu di Gampong Meurandeh Kecamatan Langsa Lama Kota Langsa, yaitu:

1) Masyarakat memahami bagaimana cara proses pembuatan Biopestisida yang terbuat dari daun bambu sebagai anti Organisme

2) Masyarakat memahami bagaimana cara penggunaan Biopestisida yang terbuat dari daun bambu sebagai anti Organisme

3) Masyarakat paham tentang bagaimana cara mempromosikan produk yang telah dibuat pada petani untuk digunakan pada tanaman yang dibudidayakan.

Pada tahapan evaluasi kegiatan masyarakat Gampong Meurandeh Kecamatan Langsa Lama Kota Langsa sudah mampu menciptakan produk unggulan nanosilika daun bambu yang siap untuk di komersialkan (Gambar 4).

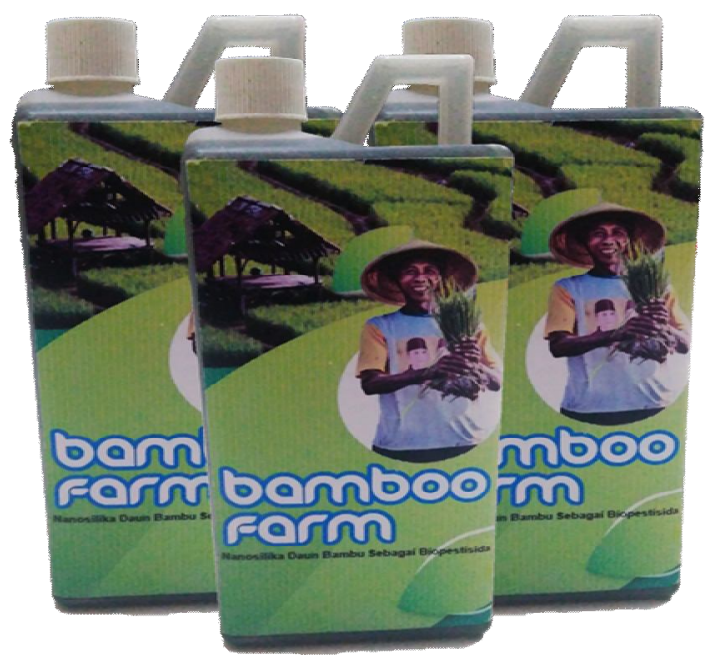

Gambar 4: Produk yang Dihasilkan 


\section{SIMPULAN}

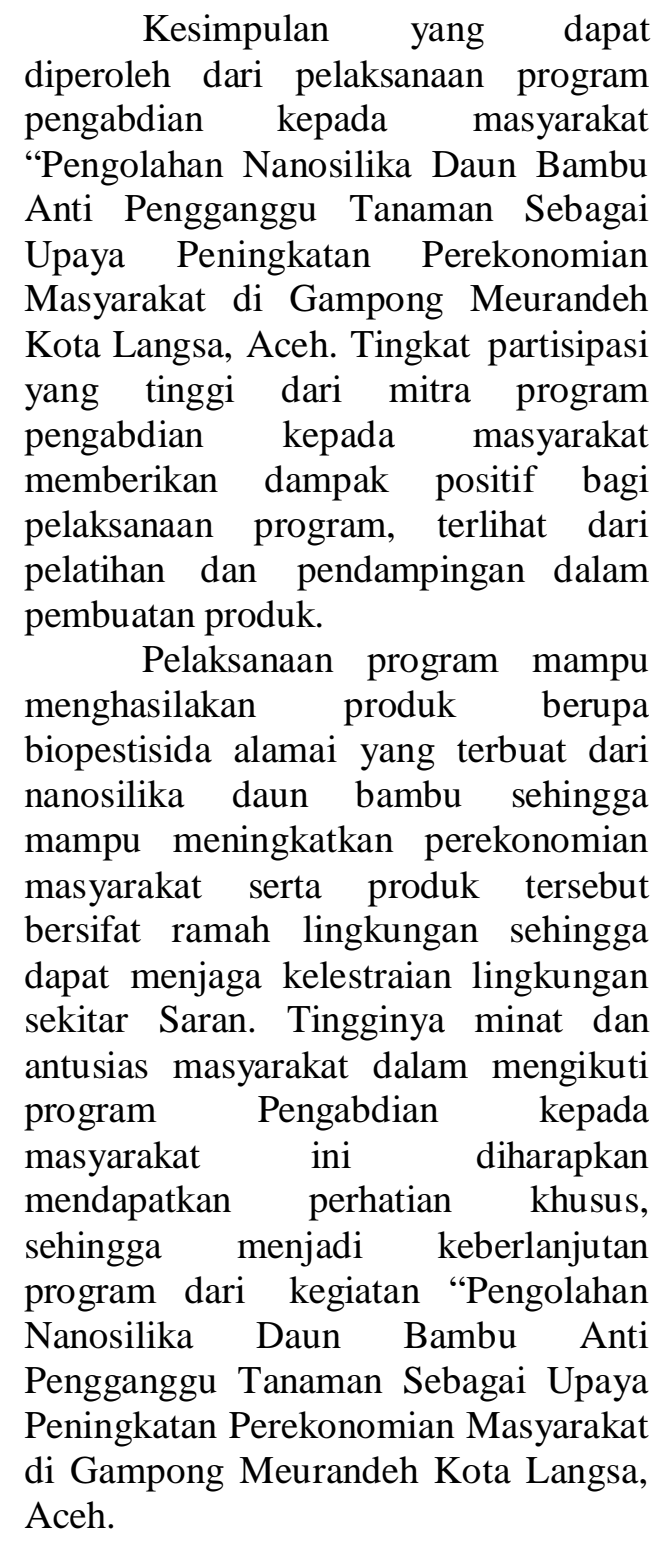

\section{UCAPAN TERIMA KASIH}

Dana Pengabdian $r$ Kepada
Masyarakat ini dibiayai oleh Daftar
Isian Pelaksana Anggaran (DIPA)
Universitas Samudra Tahun 2018
dengan nomor kontrak pengadian
kepada masyarakat
699/UN54.6/PM/2018. Nomor

\section{DAFTAR PUSTAKA}

Suhadirman, M. 2011. Kajian Pengaruh Penambahan Serat Bambu Ori Terhadap Kuat Tekan Dan Tarik Beton. Jurnal Teknik 1(2).

Amu, O. O and Adetuberu, A. A. 2010. Characteristics of Bamboo Leaf Ash Stabilization on Lateritic Soil in Higway Construction. International Jurnal of Engineering and Technolog 2(4).

Badan Litbangtan. 2010. Badan Penelitian dan Pengembangan Pertanian, Balai Pengelola Alih Teknologi. Panduan Umum Alih Teknologi Dalam Rangka Inovasi Hasil Litbang Pertanian. Badan Litbangtan Pertanian. Jakarta. Kementerian Pertanian. 